\title{
A BŐVÍTÉSI SZEMPONTOK ÉS A HATÁRON ÁTNYÚLÓ EGYÜTTMÚKÖDÉSEK KAPCSOLATA
}

\author{
(The Aspects of Enlargement and the Future of Cross-border \\ Co-operations)
}

\section{CZIMRE KLÁRA}

Kulcsszavak:

EU csatlakozás belsöés külsöhatár határ menti térség eurorégió

Az Európai Unió belsö és killsö határainak hossza jelentôs mértékben megnótt. 2004-ben az Európai Unió eddigi történetének a legnagyobb terilleti bövuliését a legnagyobb arányú és minöségileg legjelentösebb határváltozás kísérte: az EU belsỏ és külsỏ határainak arányai felcserélödtek. Az európai uniós csatlakozás következményeinek értékelésénél az a három határszakasz különül el a leginkább egymástól, amely Magyarország határait és határ menti régióit megosztja az EU csatlakozás után.

\section{A határok és a határmentiség jelensége az Európai Unióban}

A Európai Unió 2004. május 1-je előtti területét tekintve Németország rendelkezett a legtöbb szomszédos országgal (6), míg Görögország volt az egyetlen, amelynek nem volt közös szárazföldi határa egyetlenegy EU tagállammal sem. Mindössze egy-egy EU-tagállammal határos Dánia, Finnország, Írország, Nagy-Britannia, Portugália és Svédország. Természetesen, ha Európa egészét nézzük, akkor már jóval tarkább képet kapunk, hiszen így Németország szomszédos országainak a száma 8-ra ugrik, és Görögország is 3 országgal határos a szárazföldön. Az elsőként használt megközelítésre olyan esetekben lehet szükség, amikor az Európai Unióról, mint egy különálló egységrỏl beszélünk.

Európa térképét tanulmányozva az is elmondható, hogy az Európai Unió 2004 előtti állapotát tekintve a határain belül voltak olyan országok, amelyek területének több mint 50\%-a határ menti fekvésủ (Luxemburg, Ausztria, Belgium, Finnország, Svédország, Portugália), és ez az arány két ország kivételével (Dánia, NagyBritannia) - amelyek a tengerparti fekvésủknek köszönhetöen rövidebb szárazföldi határhosszal rendelkeznek - $15 \%$ feletti. A szárazföldi határok hosszát tekintve Magyarország szempontjából a szomszédos Ausztria a legérdekesebb, hiszen Ausztria szárazföldi határainak közel 15\%-a alkot közös határt Magyarországgal (356km). További három ország - Németország, Olaszország és Görögország - szárazföldi határait érintették a 2004-es és érintik a 2007-es EU bővítések (1. táblázat). 
A bővitési szempontok és a határon átnyúló együttmüködések kapcsolata.

Tér és Társadalom 18. évf. 2004/4. 117-134. p.

\section{TÁBLÁZAT}

Határ menti régiók országonkénti bontásban az Európai Unióban (2000) (Border Regions by Countries in the European Union, 2000)

\begin{tabular}{lccccc}
\hline \multicolumn{5}{c}{ Határ menti régiók az Európai Unióban } \\
\hline \multicolumn{1}{c}{ Ország } & $\begin{array}{c}\text { A szárazföldi } \\
\text { határok } \\
\text { hossza }(\mathrm{km})\end{array}$ & $\begin{array}{c}\text { Határ menti } \\
\text { régiók területe } \\
\left(\mathrm{km}^{2}\right)\end{array}$ & $\begin{array}{c}\text { Az ország } \\
\text { területének } \\
\% \text {-ában }\end{array}$ & $\begin{array}{c}\text { A határ mentiók népessége } \\
(1000 \text { fö) }\end{array}$ & $\begin{array}{c}\text { Az ország } \\
\text { népességének } \\
\text { \%-ában }\end{array}$ \\
\hline Luxemburg & 359 & 2586 & 100,0 & 381 & 100,0 \\
Ausztria & 2562 & 58199 & 69,4 & 5837 & 74,9 \\
Finnország & 2628 & 223080 & 66,6 & n.a. & n.a. \\
Belgium & 1385 & 19019 & 62,3 & 5031 & 50,5 \\
Portugália & 1214 & 50300 & 54,7 & 2068 & 21,0 \\
Svédország & 2205 & 239400 & 53,2 & $n . a$. & n.a. \\
Hollandia & 1027 & 14408 & 35,1 & 5136 & 34,4 \\
Görögország & 1228 & 37498 & 28,4 & 2359 & 23,1 \\
Spanyolország & 1918 & 132282 & 26,2 & 5378 & 14,7 \\
Németország & 3621 & 81044 & 22,7 & 13366 & 16,3 \\
Franciaország & 2889 & 115511 & 21,2 & 12637 & 22,3 \\
Írország & 360 & 12516 & 17,6 & 407 & 11,6 \\
Olaszország & 1932 & 47872 & 15,9 & 7390 & 12,8 \\
Dánia & 68 & 3930 & 9,1 & 251 & 4,9 \\
Nagy-Britannia & 360 & 14120 & 5,8 & 1589 & 2,8 \\
\hline Összesen & 23756 & 940505 & 39,2 & 61830 & 28,8 \\
\hline
\end{tabular}

Forrás: Second Report on Economic and Social Cohesion, 2001.

A határ menti térségeinek teruileti arányai többször is megváltoztak az Európai Unió története folyamán, amelyek a bővítésekből adódó teruiletváltozások eredményeként foghatók fel (2. táblázat).

Volt olyan eset, amikor a soros EU csatlakozással egy-egy határszakasz minöségileg változott meg (pl. német-dán, francia-spanyol, német-osztrák), és külső határból belső határrá alakult, illetve Németország újraegyesülésével egy korábbi határszakasz teljesen eltünt. Ezek a változások nemcsak az együttmüködés egészét befolyásolták, de maguk után vonták az újabb problémákat is, amelyek az új szomszédos tagállamokkal és nem tagállamokkal való kapcsolatokat érintették. Ezek a teriileti - és egyúttal határ- - változások nagymértékben hozzájárultak a határmentiség és a határon átnyúló kapcsolatok még intenzívebb elterjedéséhez, és ezáltal ahhoz, hogy az Európai Integráció felismerje a határon átnyúló kapcsolatok jelentőségét. 


\section{TÁBLÁZAT}

A 2004-ben csatlakozott tagországok határokra vonatkozó legfontosabb adatai (2000) (The Main Data on Borders of the Coutries Accessed in 2004)

\begin{tabular}{|c|c|c|c|c|c|c|}
\hline & $\begin{array}{c}\text { Terület } \\
\left(\mathrm{km}^{2}\right)\end{array}$ & $\begin{array}{l}\text { Népesség } \\
\text { (millió } \\
\text { fó) } \\
(2000)\end{array}$ & $\begin{array}{c}\text { Teljes } \\
\text { határhossz } \\
(\mathrm{km})^{1}\end{array}$ & $\begin{array}{c}\text { EU15 } \\
\text { területéhez } \\
\text { viszonyí- } \\
\text { tott határ- } \\
\text { pozíció }{ }^{2}\end{array}$ & $\begin{array}{c}\text { EU15-tel } \\
\text { közös } \\
\text { határ } \\
\text { hossza }^{2}\end{array}$ & $\begin{array}{c}\text { EU15 } \\
\text { külsö } \\
\text { határ } \\
\text { \%-os } \\
\text { aránya }\end{array}$ \\
\hline Csehország & 78866 & 10,3 & 1881 & $\begin{array}{l}\text { külső } \\
\text { határ }\end{array}$ & 1008 & $54 \%$ \\
\hline Észtország & 45226 & 1,4 & 633 & nincs & - & - \\
\hline Ciprus & 9250 & 0,7 & 0 & nincs & - & - \\
\hline Lettország & 64589 & 2,4 & 1150 & nincs & - & - \\
\hline Litvánia & 65200 & 3,7 & 1273 & nincs & - & - \\
\hline Magyarország & 93030 & 10,1 & 2171 & $\begin{array}{l}\text { külső } \\
\text { határ }\end{array}$ & 366 & $17 \%$ \\
\hline Málta & 316 & 0,4 & 0 & nincs & - & - \\
\hline Lengyelország & 312685 & 38,7 & 8 & $\begin{array}{l}\text { külső } \\
\text { határ }\end{array}$ & 456 & $16 \%$ \\
\hline Szlovénia & 20273 & 2,0 & 1334 & $\begin{array}{l}\text { külső } \\
\text { határ }\end{array}$ & 562 & $42 \%$ \\
\hline Szlovákia & 48845 & 5,4 & 1524 & $\begin{array}{l}\text { külsö } \\
\text { határ }\end{array}$ & 91 & $6 \%$ \\
\hline Összesen & 738280 & 75,1 & 12754 & - & 2483 & $27 \%$ \\
\hline
\end{tabular}

${ }^{\mathrm{I}}$ Teljes határhossz: szárazföldi és tengeri határok összesen.

${ }^{2}$ A vizsgálat szempontjából csak a szárazföldi határok számítanak, így a tengeri határokkal a tanulmány nem foglalkozik.

Forrás: Saját számítás.

A legközelebbi - elöreláthatólag -, 2007-es bỏvítési évben további két ország válhat EU taggá, amennyiben addigra teljesítik a csatlakozás feltételeit (4. táblázat).

\section{TÁBLÁZAT}

A várhatóan 2007-ben csatlakozó tagjelölt országok határokra vonatkozó legfontosabb adatai (2000)

(The Main Data of the Borders of the Countries Estimated to Access in 2007)

\begin{tabular}{ccccccc}
\hline & $\begin{array}{c}\text { Terület } \\
\left(\mathrm{km}^{2}\right)\end{array}$ & $\begin{array}{c}\text { Népesség } \\
(\text { millió fö }) \\
(2000)\end{array}$ & $\begin{array}{c}\text { Teljes } \\
\text { határ- } \\
\text { hossz } \\
(\mathrm{km})^{1}\end{array}$ & $\begin{array}{c}\text { EU területé- } \\
\text { hez viszo- } \\
\text { nyított határ- } \\
\text { pozíció }{ }^{2}\end{array}$ & $\begin{array}{c}\text { EU } \\
\text { külsỏ } \\
\text { határ } \\
\text { hossza } \\
(\mathrm{km})^{2}\end{array}$ & $\begin{array}{c}\text { külső } \\
\text { határ } \\
\% \text {-os } \\
\text { aránya }\end{array}$ \\
\hline Bulgária & 110910 & 8,3 & 1808 & külsö határ $^{3}$ & 1008 & $56 \%$ \\
\hline Románia & 237500 & 22,5 & 2508 & nincs $^{3}$ & - & - \\
\hline Összesen & 348410 & 30,8 & 4316 & - & 1008 & $56 \%$ \\
\hline
\end{tabular}

ITeljes határhossz: szárazföldi és tengeri határok összesen.

${ }^{2}$ A vizsgálat szempontjából csak a szárazföldi határok számítanak, így a tengeri határokkal a tanulmány nem foglalkozik.

${ }^{3}$ A vizsgálat idején nem volt határos az EU-val. 2004 után azonban Magyarország révén külső határrá változott a magyar-román határ.

Forrás: Saját számítás. 
Az új országok csatlakozásával ismét minőségi határváltozások következnek be az Európai Unióban, és minden eddiginél nagyobb arányeltolódások következnek be (5. táblázat).

\section{TÁBLÁZAT}

A határ menti térségek területi arányainak változása az Európai Unióban ${ }^{l}$ (The Development of the Border Regions' Areal Share in the European Union) ${ }^{l}$

\begin{tabular}{lccc}
\hline & EU 15(1995) & EU25 (2004) & EU27 (2007) \\
\hline EU szárazföldi határok hossza & 16097 & 23389 & 26160 \\
$(\mathrm{~km})$ & & & \\
EU szárazföldi határok száma & 33 & 55 & 62 \\
EU belsö határok száma & 15 & 30 & 33 \\
\hline az összes \%-ában & $45,5 \%$ & $54,5 \%$ & $53,2 \%$ \\
EU belsö határok hossza $(\mathrm{km})$ & 7104 & 12565 & 14110 \\
\hline az összes \%-ában & $44,1 \%$ & $53,7 \%$ & $53,9 \%$ \\
EU külsó határok száma & 18 & 25 & 29 \\
\hline az összes \%-ában & $54,5 \%$ & $45,5 \%$ & $46,8 \%$ \\
EU külső határok hossza $(\mathrm{km})$ & 8993 & 10824 & 12050 \\
\hline az összes \%-ában & $55,9 \%$ & $46,3 \%$ & $46,1 \%$ \\
\hline
\end{tabular}

${ }^{1}$ Ebben az összefüggésben a törpeállamok - Liechtenstein, Andorra, Monaco, San Marino és Vatikán nem kerültek be a számításba, mivel azok nem játszanak szerepet a határon átnyúló együttmúkơdésekben.

Forrás: Saját számítás.

Ez azt jelenti, hogy minden eddiginél nagyobb növekedés következik be az EU szárazföldi határainak a hosszát illetően, és az arányok a belső határok irányába tolódnak el (1. ábra). A szárazföldi határok hossza háromszorosára nö, míg a szárazföldi belsö határoké négyszeresére és a szárazföldi külső határoké valamivel több mint másfélszeresére emelkedik.

\section{1. ÁBRA}

Az EU szárazföldi határok hosszának változása az EU megalakulása óta eltelt idöszakban (The Change of the Mainland Borders of the European Union Since It's Foundation)
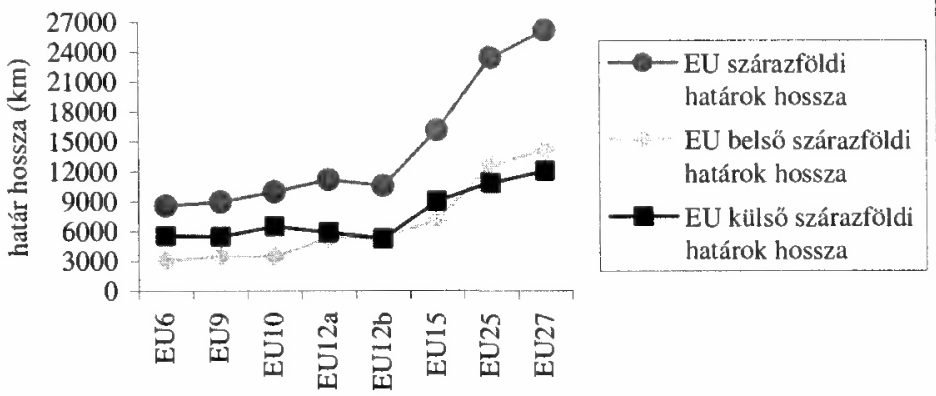

Forrás: Saját szerkesztés. 
Ez jelentős terhet jelent az EU költségvetésére, hiszen az Interreg programnak az új belső határokra történő kiterjesztésével, illetve az új külső határok mentén történő bevezetésével a mai támogatási rendszer mellett minimum háromszorosára emeli a felmerülö kiadásokat. Ugyanakkor mind az új belső, mind pedig a külső határok az európai térszerkezetben perifériális zónában fekszenek, ami még tovább fokozza ezeknek a határ menti térségeknek a forrásigényét.

Ahhoz azonban, hogy ez kivitelezhető legyen az Interreg és Phare CBC programokat össsze kell hangolni. A 21 . század első bővítési hullámában a tíz tagjelölt ország közül hat fekszik az EU15 külső határai mentén, azaz az EU felé irányuló határon átnyúló kapcsolatok ezekben az országokban a Phare $\mathrm{CBC}$ támogatás mellett az EU tagrégiókban Interreg támogatásban is részesülnek. A csatlakozás után az EU belső határára kerülő határon átnyúló együttmúköódések jogosulttá válnak az Interreg kezdeményezésre. Az EU ezért is tartotta rendkívül fontosnak az Interreg IIIA és a Phare CBC még hatékonyabb összehangolását, és az ún. Új Szomszédsági Program/Eszköz bevezetését. európai uniós csatlakozásunkat követően Magyarország határ menti statisztikai-fejlesztési régiói számára megnyílik az Európai Regionális Fejlesztési Alap Interreg programja, amelyböl 2004-ben mintegy 20 millió euró pluszforrás áll rendelkezésre a határon átnyúló együttmüködések ösztönzésére. Mindezek következtében nemcsak a régiók érdeke, de az Európai Unió számára is fontos a határon átnyúló együttmüködések támogatása és integrálása.

\section{Az EU-csatlakozás elvárásai Magyarország határ menti politikájában}

A Magyarország belsỏ átalakulásával párhuzamosan folyó külső változások generáló hatással voltak a határon átnyúló egyưttmüködések külső feltételeinek a megteremtéséhez. A hazaihoz hasonló feltételek kialakulása a szomszédos országokban csupán egyike volt a külső feltételeknek. Az Európai Unióval aláirt társulási egyezmények megszületésével párhuzamosan a határon átnyúló együittműködések is szerepet kaptak a csatlakozási folyamatban. Az EU határon átnyúló együttmüködéseket támogató forrásai megnyíltak, és nemcsak a müködési feltételek megteremtéséhez nyújtottak alapot, hanem fel is keltették az érdeklődést helyi, regionális és országos szinten is az ilyen jellegü együttmüködések iránt.

A határon átnyúló együttmüködések közül az euroregionális együttmúködések, azaz az eurorégiók váltak a legsikeresebbé és legelterjedtebbé az egész középeurópai térség területén, így Magyarországon is. Ezek az eurorégiók egyfajta hídszerepet hivatottak betölteni az Európai Unió és az azon - egyelöre - kívül eső országok között. Fontos megjegyezni, hogy ez az együttműködési forma az együttmúködök és az Európai Unió szerint is egyfajta gyakorlóterep, amely egyrészt segít az elmaradott határ menti térségek felzárkóztatásában, másrészt pedig képessé teszi a tagrégiókat és tagországokat a majdani integrációban történő aktív részvételre (Czimre 1999; Roch-Ziegler 1999; Süli-Zakar 2001).

A határ menti térségek felzárkóztatása során elsősorban a gazdasági aktivitás növelése a cél, amelyhez nagymértékben hozzájárul a külföldi múködő tőke odavonzása, az életszínvonal növekedése, a munkanélküliség csökkentése és a külkereskedelemben való intenzívebb részvétel. 
Mindezen feltételek teljesítése az ország egész területére vonatkozik, beleértve az összes határ menti térséget. Az EU azonban nem sokkal a határon átnyúló együttmüködéseket támogató programjainak a bevezetése után felismerte, hogy a tagjelölt országok azon határ menti régiói, amelyek nem érintkeznek az EU határaival, jóval nehezebb feladat előtt állnak, hiszen ,,önerőböl” kellene a fent említett területeken a helyzetüket javítaniuk. Ezek után a Phare CBC Programot Magyarország további 3 határára (magyar-román, magyar-szlovák és magyar-szlovén) is kiterjesztette.

Ausztria 1995-ös európai uniós csatlakozásával Magyarországnak kialakult egy 356 km hosszú közös határa az EU-val. Ez mindössze 16,6\%-át jelenti a határaink teljes hosszának (2 146 km). 2004. május 1-jétől azonban Magyarország határainak vonatkozásában újabb változás következett be, amelynek következtében Magyarország országhatárainak 47\%-a az Európai Unió külső határát képezi, valamint Szlovénia, Szlovákia és Magyarország csatlakozásával a korábbi 0\%-ról 53\%-ra nött Magyarország EU belső határainak aránya. Elöreláthatólag 2007-ben Románia is EU tagállammá válik, így ezután további $21 \%$-al nő a magyarországi EU belső határok aránya $(74 \%)$.

A mennyiségi változás mellett egyfajta minőségi változáson is keresztülmentek a magyarországi határok. Az Európai Unión belül Magyarország azok közé az országok közé tartozik, amelyeknek nemcsak belsö EU-s határai vannak, de külsők is. Emellett a külsö határai is megoszlanak olyan országok között, amelyek belátható időn belül tagjai lesznek az EU-nak (Románia) és olyanok, amelyek - egyelöre nem tartoznak a társult országok közé sem (Jugoszlávia, Ukrajna). A Schengeni Egyezmény elfogadásával és bevezetésével pedig jelentös változások mennek végbe határörizeti szempontból is. Az EU külső határai mentén kialakított „zárt” határok következményeként felmerül a kétség az EU külső határai mentén kialakított eurorégiók jövőjét illetỏen. Milyen hatással lesz a csatlakozásunk ezeknek az eurorégióknak a müködésére? Milyen változások várhatóak?

Annyi bizonyos, hogy mint ahogyan eddig is támogatta az EU a külső határai mentén létrejött eurorégiókat a munkájukban, úgy most is megmaradnak ezek a támogatási rendszerek, legfeljebb minőségileg - és remény szerint mennyiségileg is - átalakulnak (Phare CBC $\rightarrow$ [Új Szomszédsági Eszköz] Interreg). Ugyanakkor a külföldi müködőtőke-befektetések és az export-import tevékenység résztvevői számára a határokon történő várakozás és a bizonytalan piac miatt várhatóan negatív hatások is mutatkoznak. Ezek mellett fontos szerepet játszik a határontúli magyar kisebbség, akik egyrészt ideiglenesen (Románia), másrészt pedig hosszabb távon (Ukrajna, Jugoszlávia) az első számú vesztesei lesznek a határok megszigorításának. Valószínüsíthető, hogy a kívül maradt országok igyekeznek majd a kapcsolatok fenntartásában, mint ahogyan már évekkel ezelőtt is kimondott céljuk volt a Kárpátok Eurorégióban részt vevő román tagrégióknak az EU-hoz történő közelebb kerülés a Kárpátok Eurorégió magyar tagrégióin keresztül.

Így Magyarország többszörösen is új feladatok elé néz 2004 után, hiszen a határ menti térségeinek kapcsolatrendszerét nagyban befolyásolja majd az EU tagság (6. táblázat). 





Mindemellett a magyar külpolitika nem csupán ,nagyra értékeli a helyi kezdeményezésen alapuló eurorégiós együttmúködés valamennyi formáját a szomszédos országokkal”, de ösztönzi is az eurorégiós és a határon átnyúló együttmüködési formák létrehozását: „... a helyi és megyei önkormányzatok saját kezdeményezésük és prioritásaik alapján müködhetnek együtt határon túli partnereikkel, ami kiváló alapot biztosít a magyar EU-tagságból fakadó előnyök jövőbeni kihasználására is; a jószomszédi kapcsolatok konkrét közös projektekben öltenek testet; újabb lehetőséget kínál arra, hogy a határon túli magyarság anyaországgal fenntartott kapcsolatai tovább erösödjenek, miközben segíti öket a szülőföldjükön való boldogulásban." „A Kormány a jövöben is törekedni fog arra, hogy az eurorégiók müködését erkölcsi és anyagi támogatásban részesítse." (K/909/1) Magyarország minden megyéje és sok városa és gazdasági kamarája is - részt vesz valamilyen euroregionális együttmüködésben. Ezek közé tartoznak a Kárpátok Eurorégió, Kassa-Miskolc Eurorégió, Sajó-Rima Eurorégió, Neogradiensis Eurorégió, Ipoly Eurorégió, VágDuna-Ipoly Eurorégió, Duna-Körös-Maros-Tisza Eurorégió, Euregio West/Nyugat Pannónia, Duna-Dráva-Száva Eurorégió, Hármas Duna-vidék Eurorégió, Dráva-Mura Eurorégió, Bihar-Bihor Eurorégió, Hajdú-Bihar-Bihor Eurorégió. A vizsgálat során a Magyarország határai mentén hivatalosan nyilvántartott és müködö 13 eurorégió közül 5 került összehasonlításra, amelyek gyakorlatilag földrajzilag lefedik Magyarország teljes határhosszát, 13 határ menti megye bevonásával, valamint négy országhatárral nem rendelkezö megye is részt vesz ezekben az együttmüködésekben. Az öt eurorégió eltérő határtípusok mentén (belső, ideiglenes külső, külső) helyezkedik el, így eltérō helyzetben voltak - és lettek - az európai uniós kapcsolataikat tekintve. A vizsgálatba bevont eurorégiók legfontosabb jellemzöit a 7. táblázat foglalja össze.

A 2002-ben összeállított kérdőíves felmérés célja az EU csatlakozás elött álló Magyarország eurorégióinak vizsgálata, és müködésük egymással történő összehasonlítása. A kérdöív olyan szakembereket szólított meg, akik aktív résztvevői a Magyarország határai mentén létrejött és müködő eurorégióknak. Az alanyok alapvetỏen három csoportot képviseltek: (1) eurorégiós tanácstagok, (2) munkabizottsági tagok és (3) a titkárságok munkatársai. A felmérés csak a magyar tagrégiók képviselöire koncentrált, mivel az elsődleges cél a magyarországi helyzetkép és elvárások összehasonlítása volt. Megállapítható, hogy a különböző határok mentén elhelyezkedő eurorégiók magyar tagrégiói nagyon eltérö számú aktív résztvevővel müködnek (pl. Euregio West/Nyugat-Pannónia: 153 fö, Kárpátok Eurorégió: 26 fö, Duna-Körös-Maros-Tisza Eurorégió 12 fö, Duna-Dráva-Száva Eurorégió: 60 fö, Vág-Duna--Ipoly: 8 fö). A kiküldött kérdőívek 41\%-ára érkezett válasz (106), amely alapján az összehasonlítás elvégezhetövé vált. 


\section{TÁBLÁZAT}

A vizsgált magyarországi eurorégiók fontosabb jellemzöi (The Main Characteristics of the Examined Euroregions in Hungary)

\begin{tabular}{|c|c|c|c|c|c|}
\hline & $\begin{array}{l}\text { Kárpátok } \\
\text { Eurorégió }\end{array}$ & $\begin{array}{c}\text { Duna-Körös- } \\
\text { Maros-Tisza } \\
\text { Eurorégió } \\
\end{array}$ & $\begin{array}{c}\text { Euregio } \\
\text { West/Nyugat- } \\
\text { Pannónia } \\
\end{array}$ & $\begin{array}{c}\text { Duna-Dráva- } \\
\text { Száva } \\
\text { Eurorégió }\end{array}$ & $\begin{array}{l}\text { Vág-Duna- } \\
\text { Ipoly } \\
\text { Eurorégió }\end{array}$ \\
\hline $\begin{array}{l}\text { Hivatalos } \\
\text { megalakulás }\end{array}$ & $\begin{array}{l}1993 . \\
\text { február } 14 .\end{array}$ & $\begin{array}{c}1997 . \\
\text { november } 21 .\end{array}$ & $\begin{array}{c}1998 . \\
\text { október } 7 .\end{array}$ & $\begin{array}{c}1998 . \\
\text { november } 28 .\end{array}$ & $\begin{array}{c}1999 . \\
\text { július } 3 .\end{array}$ \\
\hline $\begin{array}{l}\text { Résztvevö } \\
\text { országok }\end{array}$ & $\begin{array}{l}\text { Magyarország, } \\
\text { Lengyelország, } \\
\text { Ukrajna, } \\
\text { Szlovákia, } \\
\text { Románia }\end{array}$ & $\begin{array}{l}\text { Magyaror- } \\
\text { szág, Romá- } \\
\text { nia, Jugoszlá- } \\
\text { via }\end{array}$ & $\begin{array}{l}\text { Magyaror- } \\
\text { szág, } \\
\text { Ausztria }\end{array}$ & $\begin{array}{l}\text { Magyaror- } \\
\text { szág, Horvát- } \\
\text { ország, } \\
\text { Bosznia- } \\
\text { Hercegovina }\end{array}$ & $\begin{array}{l}\text { Magyar- } \\
\text { ország, } \\
\text { Szlovákia }\end{array}$ \\
\hline $\begin{array}{l}\text { Tagrégiók } \\
\text { száma }\end{array}$ & 18 & 9 & 4 & 3 & 5 \\
\hline Terïlet & $161190 \mathrm{~km}^{2}$ & $77243 \mathrm{~km}^{2}$ & $15167 \mathrm{~km}^{2}$ & $23375 \mathrm{~km}^{2}$ & $24050 \mathrm{~km}^{2}$ \\
\hline Népességszám & 16194861 & 5968000 & 1268000 & 1929023 & 2763646 \\
\hline Népsürüség & 99,4 fö $/ \mathrm{km}^{2}$ & $77,3 \mathrm{fö} / \mathrm{km}^{2}$ & $83,6 \mathrm{fö} / \mathrm{km}^{2}$ & $82,5 \mathrm{fö} / \mathrm{km}^{2}$ & 115 fö $/ \mathrm{km}^{2}$ \\
\hline $\begin{array}{l}\text { Támogatási } \\
\text { formák }\end{array}$ & $\begin{array}{l}\text { Phare CBC, } \\
\text { Tacis CBC }\end{array}$ & Phare CBC & $\begin{array}{c}\text { Interreg I, IIa, } \\
\text { Illa Phare } \\
\text { CBC }\end{array}$ & Phare CBC & Phare CBC \\
\hline $\begin{array}{l}\text { Határpozíció } \\
\text { az EU15 } \\
\text { terilletéhez } \\
\text { képest }\end{array}$ & $\begin{array}{l}\text { nem EU } \\
\text { határok }\end{array}$ & $\begin{array}{l}\text { nem EU } \\
\text { határok }\end{array}$ & $\begin{array}{l}\text { EU külső } \\
\text { határ: } \\
\text { magyar- } \\
\text { osztrák }\end{array}$ & $\begin{array}{l}\text { nem EU } \\
\text { határok }\end{array}$ & $\begin{array}{l}\text { nem EU } \\
\text { határ }\end{array}$ \\
\hline & $\begin{array}{c}\text { EU belső } \\
\text { határ: magyar- } \\
\text { szlovák, len- } \\
\text { gyel-szlovák, } \\
\text { magyar-ukrán, }\end{array}$ & $\begin{array}{l}\text { EU kỉilső } \\
\text { határ: } \\
\text { magyar- } \\
\text { román }\end{array}$ & $\begin{array}{l}\text { EU belsỏ } \\
\text { határ: } \\
\text { magyar- } \\
\text { osztrák }\end{array}$ & $\begin{array}{l}\text { EU külső } \\
\text { határ: } \\
\text { magyar- } \\
\text { horvát }\end{array}$ & $\begin{array}{l}\text { EU belsó } \\
\text { határ: } \\
\text { magyar- } \\
\text { szlovák }\end{array}$ \\
\hline $\begin{array}{l}\text { Határpozíció } \\
2004 \text { utín }\end{array}$ & $\begin{array}{l}\text { lengyel-ukrán, } \\
\text { EU külső } \\
\text { határ: szlovák- } \\
\text { ukrán, ma- } \\
\text { gyar-román, } \\
\text { nem EU határ: } \\
\text { román-ukrán }\end{array}$ & $\begin{array}{c}\text { magyar- } \\
\text { jugoszláv } \\
\text { román- } \\
\text { jugoszláv }\end{array}$ & & $\begin{array}{c}\text { nem EU határ: } \\
\text { bosnyák- } \\
\text { horvát }\end{array}$ & \\
\hline $\begin{array}{l}\text { Internetes } \\
\text { elérhetöség }\end{array}$ & $\begin{array}{l}\text { A meglévő } \\
\text { angol és len- } \\
\text { gyel nyelvü } \\
\text { elérhetőség } \\
\text { kielégítő. } \\
\text { Bővítésre } \\
\text { szorul. }\end{array}$ & $\begin{array}{l}\text { Hiányos, az } \\
\text { alapadatokon és } \\
\text { ismereteken } \\
\text { kívül csak a } \\
\text { környezetvé- } \\
\text { delmi projektrỏl } \\
\text { tájékoztat. }\end{array}$ & $\begin{array}{l}\text { Igényes, } \\
\text { részletes. }\end{array}$ & $\begin{array}{l}\text { Szépen meg- } \\
\text { szerkesztett, } \\
\text { több nyelvü } \\
\text { honlap - habár } \\
\text { frissítve már } \\
\text { régen volt. }\end{array}$ & $\begin{array}{l}\text { Egyáltalán } \\
\text { nincs még } \\
\text { honlapja. }\end{array}$ \\
\hline $\begin{array}{l}\text { Kutatási } \\
\text { lefedettség }\end{array}$ & $\begin{array}{l}\text { Részletesen } \\
\text { kutatott, } \\
\text { teljesen lefedik } \\
\text { a kutatások. }\end{array}$ & $\begin{array}{l}\text { Elsősorban a } \\
\text { közös környe- } \\
\text { zetvédelmi } \\
\text { kérdéseket } \\
\text { érintik a } \\
\text { kutatások. }\end{array}$ & $\begin{array}{l}\text { Részletesen } \\
\text { kutatott, telje- } \\
\text { sen lefedik a } \\
\text { kutatások. }\end{array}$ & $\begin{array}{l}\text { Kevésbé } \\
\text { részletesen } \\
\text { kutatott, mint } \\
\text { az előző két } \\
\text { eurorégió. }\end{array}$ & $\begin{array}{l}\text { Legkevésbé } \\
\text { ismert és } \\
\text { legkevésbé } \\
\text { kutatott jelen- } \\
\text { leg az euro- } \\
\text { régiók közül } \\
\text { Magyar- } \\
\text { országon. }\end{array}$ \\
\hline
\end{tabular}

Forrás: Saját szerkesztés. 
A tanulmány az eurorégiókat az Európai Unió bővítésének és annak hatásainak szemszögéböl hasonlítja össze, így a kérdőíves felmérés egyéb eredményeivel itt nem foglalkozik.

\section{A vizsgált eurorégiók fennmaradási esélyei}

A válaszadók $88,5 \%$-a úgy látja, hogy az eurorégió intézménye életképes együttmüködési forma a mai Közép-Európában. A Duna-Dráva-Száva Eurorégió (75\%) és a Kárpátok Eurorégió $(85,7 \%)$ képviselöi azok, akik az átlag alatt maradnak. Meglepő a Duna-Körös-Maros-Tisza Eurorégió képviselöinek a pozitív hozzáállása, mivel ennek az eurorégiónak a három tagországa közül mindössze Magyarország vált EU taggá 2004. május 1-jével. Elöreláthatólag Románia három évvel később csatlakozik, de a magyar-jugoszláv és a román-jugoszláv határ még hosszú ideig EU külső határ marad, amely a schengeni egyezmény értelmében zárt és szigorúan ellenőrzött lesz. Ez pedig gátja lehet az együttmüködés intenzív elmélýitésének.

Az elkövetkezö öt évben várhatóan jelentös változásokon mennek keresztül mind Magyarország, mind pedig azok a szomszédos országok, amelyekkel jelenleg euroregionális kapcsolatban áll. A legtöbben úgy gondolják (50\%), hogy az EU csatlakozásunkat követően, a határátkelés ellenőrzésének egyszerüsödésével, majd megszünésével, és így az euroregionális együttműködéseknek a szerepe átértékelödik. A válaszadók mindössze 7,7\%-a látja úgy, hogy az EU csatlakozással párhuzamosan, annak egyik velejárójaként megszủnik az általa képviselt eurorégió.

Területi bontásban nézve még érdekesebb az eredmény. Az Euregio West/Nyugat Pannónia $(60 \%)$ és a Vág-Duna-Ipoly (100\%) képviselői gondolják úgy a legtöbben, hogy meg fognak szünni az államhatárok, és ezzel párhuzamosan átértékelődik az eurorégiók szerepe. Itt a válaszadók olyan eurorégiók területén élnek, amelyek tagrégiói 2004-től mind Európai Uniós tagállamok területéről kerülnek ki. Természetesen a változást számukra elsősorban az EU regionális politikája, illetve a Strukturális Alapok átrendeződése jelenti. Ugyanakkor várhatóan ezeknek az eurorégióknak a területén a Schengeni Egyezmény értelmében még jobban leegyszerüsödik a tóke és az információ áramlása, és így a tagrégiók között a kapcsolat még intenzívebbé válhat.

A legmegosztottabb a vélemény a Kárpátok Eurorégió és a Duna-Dráva-Száva területén. Itt még azok is viszonylag magas arányt képviselnek, akik úgy gondolják, hogy az EU-csatlakozással párhuzamosan megszünik az eurorégió. Természetesen ez annak tudható be, hogy a magyar eurorégiós partnereken kívül a szomszédos országok közül néhányan az EU-n kívül maradnak (Kárpátok Eurorégió: Ukrajna, Románia - ideiglenesen; Duna-Dráva-Száva: Bosznia-Hercegovina, Horvátország).

A Kárpátok Eurorégióban és a Duna-Körös-Maros-Tisza Eurorégióban a résztvevők véleménye szerint az EU csatlakozás után az eurorégiók nemcsak hogy fennmaradnak, de aktívan részt fognak venni az EU munkájában. Ez elsősorban azt jelenti, hogy a tagországok révén egyes régiók az EU támogatási formáit a térségbe 
hozzák, illetve még jobban megismertetik és fejleszteni fogják azokat az eurorégiós tagrégiókat, amelyek kívül esnek az EU határain.

Ha egy Magyarország térképre visszük eurorégiónként azt az adatot, amely a legtöbbször szerepel válaszként, akkor a csatlakozás következményeként kialakuló korábban vázolt - határtípusok rajzolódnak ki (2. ábra).

\section{2. ÁBRA}

Az eurorégió jövője öt év múlva - a leggyakrabban megjelölt változó alapján

$$
(\Sigma=106)
$$

(The Future of the Euroregion in 5 Years by the Most Frequently Marked Variable)

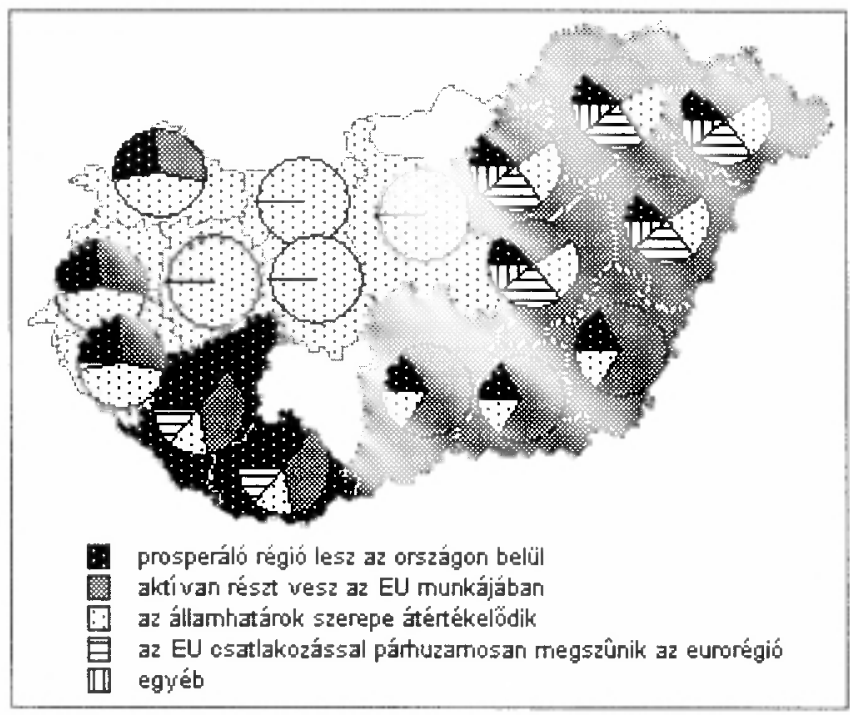

Forrás: Saját szerkesztés.

Elöfordulhat az is, hogy az eurorégiók nem bomlanak fel teljesen a jö vöben, csupán néhány tagrégió kiválik belőlük. Ezt a kérdést illetően rendkívül megosztottak a válaszadók, mégis legtöbben (43\%) úgy gondolják, hogy nem lesznek olyan tagrégiók, amelyek ki fognak válni. Azonban az ,igen" válaszok meglehetősen magas aránya (31\%) azt sugallja, hogy jelentös területi különbségek húzódnak meg emögött az eredmény mögött.

A Kárpátok Eurorégió (50\%) és a Duna-Körös-Maros-Tisza Eurorégió (40\%) esetében a legmagasabb azoknak az aránya, akik úgy gondolják, hogy ki fognak válni egyes régiók a jelenlegi együttmúködési formából. A Kárpátok Eurorégióban ez az arány messze meghaladja azoknak a számát, akik nem tartják elképzelhetőnek a kiválást. A Duna-Körös-Maros-Tisza Eurorégió esetében ez az arány azonos.

Az Euregio West/Nyugat Pannónia (50\%) és a Duna-Dráva-Száva Eurorégió (50\%) képviselöi állítják a legmagasabb arányban, hogy nem várható egyes tagrégióknak a kilépése, míg a Vág-Duna-Ipoly Eurorégió válaszadói közül senki nem gondolja, hogy lennének tagrégiók, amelyek kiválnak. Ez utóbbi esetben azonban 
vannak olyanok, akik bizonytalanok a kérdést illetően, és nem tudtak válaszolni. Az optimizmus és a pesszimizmus e sajátos keverékének a magyarázatát ismét a térképre tekintve lelhetjük meg. Hasonlóképpen, mint az elöző térképvázlaton, itt is a korábban tárgyalt határtípusok rajzolódnak ki előttünk (3. ábra).

3. ÁBRA

Elképzelhetönek tartja-e egyes tagok kiválását az Ön által képviselt eurorégióból? $(\Sigma=106)$

(Can You Imagine That Some of the Members Leave the Euroregion You Represent?)



Forrás: Saját szerkesztés.

Azt, hogy milyen motivációi lehetnek egy tagrégiónak a kiválásra, többféleképpen indokolták nemcsak azok, akik szerint elképzelhetô tagok kiválása a vizsgált euroregionális együttmúködésekböl, hanem azok is, akik nemleges választ adtak, vagy nem tudták a választ. A leggyakrabban említett tényezö a politikai ok $(39,7 \%)$ volt, illetve a válaszadók 27,9\%-a szerint egyes tagrégióknak az EU csatlakozás révén elönyösebb pozícióba kerülése szintén a kiválást eredményezheti (elszakad a gyengébb tagrégióktól).

Az eurorégiók között jelentős különbségek vannak a kiválást elöidéző okok terén is. A politikai okok dominánsak a Kárpátok Eurorégió $(53,8 \%)$ és a Vág-DunaIpoly Eurorégió (100\%) esetében. Ugyanakkor a Duna-Dráva-Száva Eurorégió és az Euregio West/Nyugat Pannónia esetében az EU csatlakozást nevezik meg elsődlegesen lehetséges okként a kiválásra. Míg az előbbi esetben az előnytelenebb pozícióba $(42,9 \%)$ kerülés vezeti a sort, addig az utóbbinál az egyes tagrégiók előnyösebb pozícióba jutása $(40,5 \%)$ válthatja ki a kilépést. A lehetséges okok közül a domináns okok kiválasztásával és térképi ábrázolásával kitünik az egyes határtípusok hatása egy-egy eurorégió mủködésére (4. ábra). 


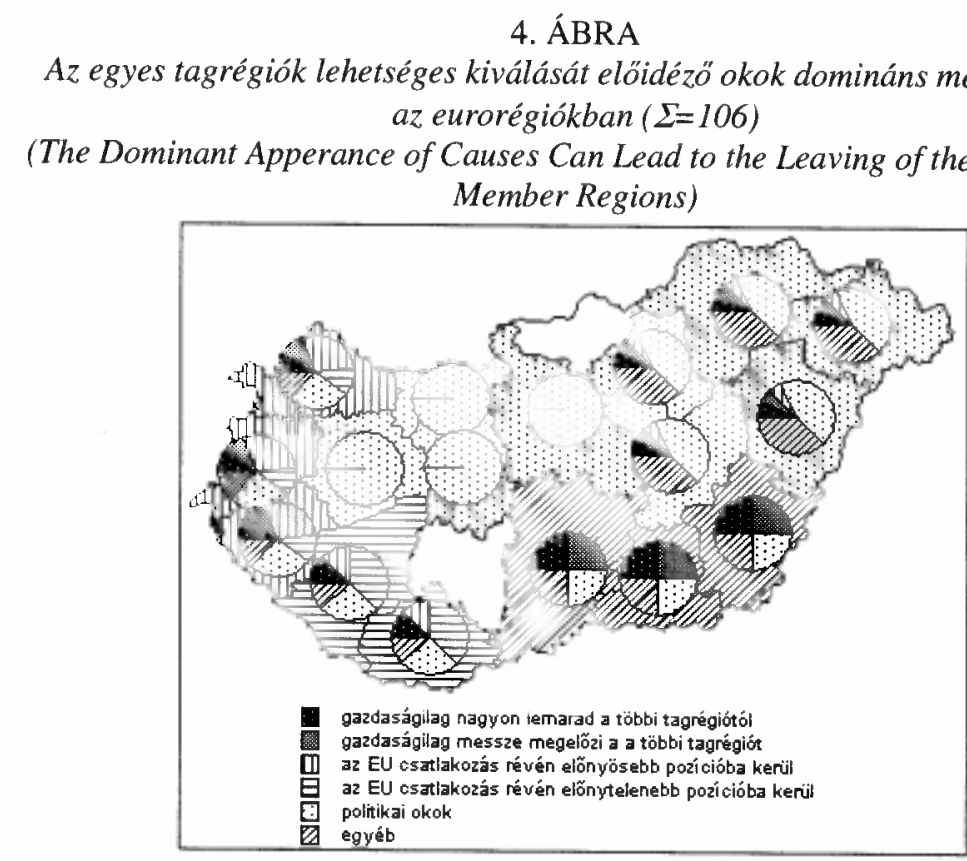

Forrás: Saját szerkesztés.

Az egyéb kategórián belül az egyes eurorégiók képviselöi különböző okokat emlitettek, amelyek nagyrészt alátámasztják az eddigi elemzés alapján kapott eredményeket.

A Kárpátok Eurorégióban az érdektelenséget, ,érdekmúlást” és az érdekeltségi rendszer hiányát említik a legtöbben (50\%), különösképpen a helyi politikusok érdektelenségét kiemelve. Az anyagi problémák - tagdíj késedelmek és elmaradások - szintén többek szerint hozzájárulhatnak az egyes tagrégiók kiválásához. Volt olyan válaszadó is, aki a mủködésképtelenség felismerését tartotta a kiválást előidézö legföbb oknak.

A Duna-Körös-Maros-Tisza Eurorégióban az egyéb okok között a legfontosabbnak a pénzügyi problémákat találták - hangsúlyozva a tagdíjfizetési kötelezettségbỏl származó gondokat.

Az Euregio West/Nyugat Pannónia megkérdezettjei a földrajzi távolságot, a többi eurorégiós területhez való közelséget vagy régióközponttól való távolságot, illetve a gazdasági vonzásirányok átrendeződését említik. Az egyik válaszadó megfogalmazása szerint az „infrastrukturális elérhetőség hiánya nem teszi lehetővé a kohéziót”, és ez hozzájárulhat egyes tagok kiválásához. Volt olyan is, aki szerint a személyes indokok és az esetleges rivalizálás is befolyásolhatja egy adott régió eurorégiós tagságát.

Az egyik válaszadó részletesen kifejti, hogy mivel „Más szerveződésü eurorégiók is létrejöhetnek, újak is létrejöhetnek a földrajzi-gazdasági adottságok (hasonlóságok) alapján, igy a mai eurorégiók átrendezödése lehetséges. Ebben szerepet játszhat az esetleg eltérö idöpontú EU csatlakozás is." Erre az elmúlt években több példát is láthattunk, hiszen a Kárpátok Eurorégió területén sorra alakulnak az euroregionális jellegủ szervezödések, mint például a Bihar-Bihor Eurorégió, a 
Miskolc-Kassa Eurorégió vagy a Sajó-Rima Eurorégió, hogy csak a magyar tagrégiókkal müködöket említsük. Hasonlóképpen igaz ez a magyar-horvát-szlovénosztrák határtérségben is, ahol a két tárgyalt eurorégión kívül nemrégiben alakult meg a Dráva-Mura Eurorégió is.

Ahhoz, hogy az együttmüködések fennmaradjanak, természetesen a megfelelö anyagi háttér biztosítása elengedhetetlen. Az együttmüködések számára különbözö források állnak rendelkezésre: európai uniós támogatási alapok, állami támogatások és különböző alapítványok vagy egyesületek hozzájárulásai. Az EU Alapok elérhetösége az egyes határtípusok mentén eltérően alakult, aminek következtében az egyes eurorégiókban különbözik az ezeknek a forrásoknak az ismerete is. A VágDuna-Ipoly Eurorégió képviselöinek a kivételével mindegyik forrást említették a képviselök, sőt az Euregio West/Nyugat Pannónia és a Duna-Dráva-Száva Eurorégió esetében számos egyéb forrást is említettek. Ilyenek voltak például az Euregio West/Nyugat Pannónia esetében az EQUAL, az ISPA, a SAPARD és a Nyugat-Dunántúli Regionális Fejlesztési Tanács pályázati lehetőségei. A DunaDráva-Szávánál szintén szerepelt az ISPA, mint a térségben elérhető forrás, illetve említették még az ORPHEUS programot.

A Phare CREDO program egy viszonylag rövid periódusra vonatkozott, és a Phare CBC földrajzi kiterjesztésével azt meg is szüntették. Mégis többen említették, ami arra utal, hogy korábban nyújtottak be pályázatot ehhez a forráshoz is. Meglepö, hogy a Kárpátok Eurorégió és a Duna-Dráva-Száva képviselöinek csak alig több mint 70\%-a hallott a Phare CBC-röl. Ennek a magyarázata az elözőéhez hasonló. Mivel a Phare CBC-t mindössze 1998-ban terjesztették ki azokra a határokra, amelyek nem határosak az EU-val, így az ezeken a határszakaszokon még kevésbé bejáratott ez a támogatási rendszer. Összességében megállapítható, hogy az összes megkérdezett közül legnagyobb arányban a Phare CBC és az Interreg támogatási formáit ismerik (5. ábra).

\section{5. ÁBRA}

A támogatási rendszerek ismerete az összes megkérdezett körében $(\Sigma=106)$

(The Knowledge of Supporting Systems among All Pollee)

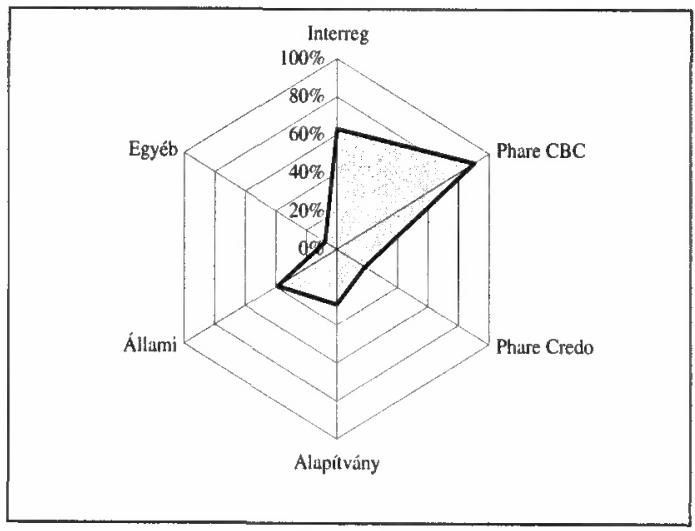

Forrás: Saját szerkesztés. 


\section{Az EU-csatlakozás következményei}

A kérdés, hogy vajon az euroregionális együttmüködés elösegíti-e az érintett országok EU csatlakozását, 87\%-ban pozitív választ hozott. Ebben a tekintetben a Kárpátok Eurorégió képviselöi bizonyultak a legmegosztottabbaknak: $64 \%$ igennel, $21 \%$ nemmel válaszolt, míg a maradék $15 \%$ azt mondta, hogy nem tudja. Ez a szkepticizmus elsősorban azzal magyarázható, hogy ez az eurorégió mutatja a legnagyobb változatosságot a vizsgáltak közül mind a résztvevő országok nagyságát, mind pedig a résztvevő országok közötti csatlakozási tárgyalások állását illetően. Mindemellett az eurorégiók képviselöinek legnagyobb része úgy gondolta 2002-ben, hogy az együttmüködés hatékonysága és eredményessége terén változás fog bekövetkezni az érintett országok európai uniós csatlakozása után.

A válaszadók közül senki nem gondolta úgy, hogy az euroregionális együttmúködések lelassíthatják az érintett országok EU csatlakozását, de azt is kevesen gondolták, hogy felgyorsítaná azt. A Duna-Körös-Maros-Tisza Eurorégió és a VágDuna-Ipoly Eurorégió képviselöi egyáltalán nem gondolják úgy, hogy felgyorsítaná a folyamatot, és a Duna-Dráva-Száva Eurégió képviselöinek is mindössze 9\%-a szerint vannak az euroregionális együttmüködések gyorsító hatással a csatlakozási folyamatokra. Ezen a téren a Kárpátok Eurorégió (38,5\%) és az Euregio West/Nyugat Pannónia $(30,6 \%)$ voltak a legbizakodóbbak. A legtöbben $(48,5 \%)$ azt tartják fontosnak, hogy az eurorégiók segítik a tagrégiókat az integrációs követelmények megismerésében - ez kifejezetten a Duna-Körös-Maros-Tisza Euro-régió (100\%) és az Euregio West/Nyugat Pannónia (52,8\%) esetében volt így, míg a Kárpátok Eurorégió (23\%) esetében számított a legkevésbé.

Hasonló az arány a pályázatok útján történő fejlödésnek indulás és a perifériális jelleg csökkentésére gyakorolt hatás megítélésében is: a Vág-Duna-Ipoly $(66,6 \%)$ és a Duna-Dráva-Száva Eurorégió $(45,5 \%)$ számára volt a legfontosabb, ugyanakkor a Kárpátok Eurorégió (23\%) képviselöi ezt sem tartották annyira lényeges szempontnak.

Közel egységes - ám relatíve alacsony arányú - volt az álláspont (20-38\%) azt illetően, hogy az eurorégiók megismertetik a résztvevő tagrégiókat az Európai Unióval. Ez azért is meglepö, mivel az eurorégiókat az AEBR intézménye elismeri és koordinálja a munkájukat, másrészről pedig a pályázati tevékenységeken (Phare CBC) keresztül kapcsolatot tartanak fenn az EU illetékes szervezeteivel.

Már a korábbiakban többször esett szó az eurorégiók fennmaradásához szükséges anyagi támogatásokról. Ezek a pályázati lehetőségek az EU csatlakozással szintén átalakulnak. Arról, hogy az átalakulást közvetlenül pontosan mi okozza, megoszlik a vélemény. Annyiban viszonylag egységes az álláspont ( $95 \%$ ), hogy megjelennek új támogatási formák az EU csatlakozást követően, ennek formája azonban három terület között oszlik meg: legnagyobb részt az európai uniós csatlakozás révén megnyíló fö forrásokat nevezik meg a megkérdezettek (68\%), ezt követik az állami politikai fordulatok következményeként teremtett új pályázati lehetöségek (20\%), és nem sokkal mögötte az alapítványok és szponzorok támogatását (18\%) említik. 
A Duna-Körös-Maros-Tisza Eurorégió képviselöi kizárólag a csatlakozás révén megnyíló forrásokban látják a reményt (100\%). Ez a határszakaszon jelenleg elérhető Phare CBC forrásoknak az Interreg IIIA költségvetéshez történő átsorolását jelenti számukra.

Az állami politikai fordulatok szerepét a Duna-Dráva-Száva Eurorégió $(33,3 \%)$ és az Euregio West/Nyugat Pannónia (23,9\%) képviselői látják a pénzügyi források második legfontosabb lehetőségének, míg a többi eurorégió képviselői egyáltalán nem említik meg ezt a tényezót.

Az új alapítványok és szponzorok megjelenését illetően elsősorban a Vág-DunaIpoly Eurorégió (33,3\%) és a Kárpátok Eurorégió (23,1\%) esetében magas azoknak az aránya, akik ezektöl az eszközöktől is remélnek támogatást a jövőben (is).

\title{
Összegzés
}

Magyarország határainak az európai uniós csatlakozást követően kialakult megosztottságát tükrözik az eurorégiókban várható változások, amelyeket az alábbi módon foglalhatjuk össze:

\author{
8. TÁBLÁZAT \\ Az eurorégiókban várható változások \\ (Expected Changes in Euroregions)
}

\begin{tabular}{|c|c|c|c|}
\hline & $\begin{array}{c}\text { Az eurorégió jövőjére } \\
\text { vonatkozó lehetséges } \\
\text { változások }\end{array}$ & $\begin{array}{l}\text { Az egyes tagok } \\
\text { lehetséges kiválá- } \\
\text { sát elóidézó okok }\end{array}$ & $\begin{array}{l}\text { Az euroregionális } \\
\text { együttmüködés } \\
\text { EU csatlakozásra } \\
\text { gyakorolt hatása }\end{array}$ \\
\hline $\begin{array}{l}\text { Belsö } \\
\text { határ }\end{array}$ & $\begin{array}{l}\text { Megszủnik a határát- } \\
\text { kelés ellenörzése és } \\
\text { átalakul az eurorégiók } \\
\text { szerepe }\end{array}$ & $\begin{array}{l}\text { Az Európai Unión } \\
\text { belüli elönyösebb } \\
\text { pozícióba kerülés }\end{array}$ & $\begin{array}{l}\text { Hozzájárulás a } \\
\text { csatlakozási fo- } \\
\text { lyamat felgyorsu- } \\
\text { lásához }\end{array}$ \\
\hline $\begin{array}{l}\text { Külsö } \\
\text { hatâr }\end{array}$ & $\begin{array}{l}\text { A részt vevö magyar } \\
\text { régiók az országon } \\
\text { belül lesznek pros- } \\
\text { peráló régiók }\end{array}$ & $\begin{array}{l}\text { Az Európai Unión } \\
\text { belüli előnytele- } \\
\text { nebb pozícióba } \\
\text { kerülés }\end{array}$ & $\begin{array}{l}\text { A perifériális jelleg } \\
\text { csökkentése }\end{array}$ \\
\hline $\begin{array}{l}\text { Ideiglenes } \\
\quad \text { külsö } \\
\text { határ }\end{array}$ & $\begin{array}{l}\text { Az érintett régiók } \\
\text { aktív szerepet kapnak } \\
\text { az EU munkájában }\end{array}$ & Politikai okok & $\begin{array}{l}\text { Megismerteti a } \\
\text { részt vevő régiókat } \\
\text { az Európai Unióval }\end{array}$ \\
\hline
\end{tabular}

Forrás: Saját szerkesztés.

Mint ahogyan a magyarországi résztvevőkkel alakult eurorégióknak vannak elvárásaik az Európai Unióval szemben a csatlakozási folyamatok során, ugyanúgy az Európai Unió is figyelemmel kíséri a létrejött eurorégiók munkáját és eredményeit. Természetesen az eurorégiók nemcsak úgy tudnak átmenni az európai uniós alkalmassági vizsgán, hogyha a tagrégióikat fejlesztik és a tagrégiók közötti kapcsolatokat elmélyítik. Mindemellett szükség van arra is, hogy a többi eurorégióval, 
azaz a többi, akár Magyarországhoz, akár a szomszédos országhoz tartozó határ menti térséggel is összehangolják tevékenységeiket, hiszen így tudják bizonyítani, hogy érettek a magasabb szintủ integrációban való részvételre. Ez az intereuroregionális kapcsolat több irányú lehet:

1) EU15 belsö határok mentén létrejött eurorégiók kal;

2) EU15 külső határai mentén elhelyezkedő közép-európai eurorégiókkal;

3) EU25 külső határok mentén elhelyezkedỏ eurorégiókkal.

Magyarország határ menti térségei számára mindenképpen kitörési pontként értelmezhetőek az eurorégiók, amelyek segítenek a perifériális helyzet felszámolásában és felkészitik az érintett régiókat az integrációra. Az összefogással és az Európai Unió támogatásával látványos fejlödést produkálhatnak, amennyiben képesek azokat megfelelöen hasznosítani és az elönyükre fordítani. A következö évek és évtizedek eredményei és gazdasági-társadalmi mutatói fogják bizonyítani, hogy mennyire életképes formái az együttmúködésnek.

\section{Irodalom}

Czimre K. (1999) Eurorégiók a Régiók Európájában. - Szónokyné Ancsin G. (szerk.) Határok és régiók. Szegedi Tudományegyetem Természettudományi Kar, Gazdaság és Társadalomföldrajz Tanszék, Szeged. 77-85. o.

Roch, I.-Ziegler, A. (1999) A határmentiség fejlödése és az európai kooperatív gyakorlat. - Tér és Tairsadalom. 1-2. 129-141, o.

Süli-Zakar, I. (2001) Euroregionalism in Central Eastern Europe: Case Study: Carpathian Euroregion. Suili-Zakar, I.-Czimre, K. (eds.) Carpathian Euroregion: Borders in the Regions - Cross-Border Cooperation. Kossuth Egyetemi Kiadó, Debrecen. 18-32. o.

Szemlér T. (2001) Euroregionális együttmüködési minták és EU-források. MTA Világgazdasági Kutatóintézet, Budapest. 